\title{
TWO-STAGE FERMENTATION FOR LACTIC ACID PRODUCTION ON DISTILLERY STILLAGE
}

\section{DVOSTEPENA FERMENTACIJA ZA PROIZVODNJU MLEČNE KISELINE NA DESTILERIJSKOJ DŽIBRI}

\author{
Dragana MLADENOVIĆ, Aleksandra DJUKIĆ-VUKOVIĆ*, Miloš RADOSAVLJEVIĆ ${ }^{* *}$, \\ Jelena PEJIN**, Sunčica KOCIĆ-TANACKOV ${ }^{* *}$, Ljiljana MOJOVIĆ \\ *University of Belgrade, Faculty of Technology and Metallurgy, 11000 Belgrade, Karnegijeva 4, Serbia \\ ${ }^{* *}$ University of Novi Sad, Faculty of Technology, 21000 Novi Sad, Bulevar cara Lazara 1, Serbia \\ e-mail:dmladenovic@tmf.bg.ac.rs
}

\begin{abstract}
The aim of this study was to assess utilization of distillery stillage in a two-stage fermentation using Bacillus licheniformis TFUNS and Lactobacillus paracasei NRRL B-4564. In the first stage the stillage was pretreated with B. licheniformis which is an efficient producer of proteolytic enzymes, in order to increase the content of free $\alpha$-amino nitrogen in the waste substrate. In the subsequent stage the lactic acid (LA) fermentation by L. paracasei was performed. The results of the fermentation of proteolytically pretreated stillage (i.e. of two-stage fermentation) were compared with the untreated stillage (one-stage fermentation).

The results have shown that the amount of free $\alpha$-amino nitrogen in pretreated media was $107 \%$ higher compared to the initial value. The concentration of the LA obtained in the second stage by L. paracasei was $48 \%$ higher than in untreated stillage. In addition, the growth of L. paracasei in pretreated stillage was also better supported compared to that in untreated media. The process enabled economical and sufficient supply of easily assimilative nitrogen sources needed for lactic acid bacteria, thus avoiding addition of costly sources in the media commonly performed in LA production.
\end{abstract}

Key words: distillery stillage, lactic acid, two-stage fermentation, Bacillus licheniformis, Lactobacillus paracasei.

\section{REZIME}

Iskorišćavanje biomase druge generacije (lignocelulozni materijali i agro-industrijski otpad) predstavlja potencijalno održiv $i$ ekološki prihvatljiv način za proizvodnju mlečne kiseline (MK). Međutim, zbog izrazitih nutritivnih potreba bakterija mlečne kiseline, pre svega u pogledu izvora azota, šećera, minerala i vitamina, proizvodnja MK fermentacijom sirovina druge generacije nije lak zadatak. Cilj ovog rada bio je da se ispita mogućnost dvostepene fermentacije destilerijske krompirove džibre pomoću sojeva Bacillus licheniformis TFUNS i Lactobacillus paracasei NRRL B-4564. U prvoj fazi džibra je inokulisana proteolitičkim sojem B. licheniformis u cilju povećanja sadržaja slobodnog a-amino azota, a time i poboljšanja hemijskog sastava supstrata za mlečnokiselinsku fermentaciju. U narednoj fazi džibra je podvrgnuta mlečno-kiselinskoj fermentaciji pomoću L. paracasei. Rezultati fermentacije proteolitički tretirane džibre (dvostepena fermentacija) su upoređeni sa parametrima postignutim u fermentaciji netretirane džibre (jednostepena fermentacija).

Koncentracija slobodnog $\alpha$-amino azota u tretiranoj džibri je bila $107 \%$ veća u odnosu na početnu vrednost. Povećanje sadržaja slobodnog $\alpha$-amino azota u medijumu je rezultat aktivnosti proteolitičkih enzima koji katalizuju hidrolizu proteina u džibri. Koncentracija MK postignuta u fermentaciji tretirane džibre je bila 48\% veća u odnosu na netretirani medijum. Pored povećanja koncentracije $M K$, u tretiranoj džibri je uočen i bolji rast L. paracasei, što se može objasniti povoljnijim odnosom sadržaja ugljenika i azota u medijumu, odnosno povoljnijim hemijskim sastavom tretirane džibre za rast bakterija, a time i za proizvodnju MK. Procesom dvostepene fermentacije je omogućeno ekonomično obogaćivanje medijuma lako dostupnim izvorima azota neophodnih bakterijama mlečne kiseline, čime se može delimično ili potpuno izbeći dodavanje skupih, najčešće korišćenih izvora azota.

Ključne reči: destilerijska džibra, dvostepena fermentacija, mlečna kiselina, Bacillus licheniformis, Lactobacillus paracasei.

\section{INTRODUCTION}

Lactic acid (LA) is a valuable chemical with widespread applications in pharmaceutical, cosmetic, chemical as well as food industries. Recently, consumption of LA has increased considerably, mainly because of its role as a starting raw material for the production of green, biodegradable and biocompatible polylactic acid (PLA) polymers. Up to now, almost all of the LA used globally is obtained by the fermentative production route and many attempts have been made to select low-cost materials and develop a sustainable and efficient fermentation strategy for LA production. Fermentation of second generation biomass (lignocellulosic biomass, agricultural residues or waste streams) is a potentially sustainable and environmentally friendly way for LA production. However, since the lactic acid bacteria (LAB) are nutritionally rather demanding strains, especially regarding the sources of nitrogen, sugars, minerals and vitamins, the utilization of the second generation biomass is not an easy task. This is mostly because the second generation biomass is usually nutritionally poor and/or of a complex chemical structure.

An effective LA production on waste and renewable substrates requires not only sugars as a main carbon source, but also proteins or total nitrogen have been often highlighted as the second important characteristic of media that must be considered responsible for improvement of LA productivity (DjukićVuković et al., 2016). The proteolytic system of LAB is known to be limiting and the substances such as amino acids, peptides, and nucleic acid derivatives must be added to the growth medium (Thomsen et al., 2007). To supply all these ingredients, yeast extract and protein lysates (peptones) have been widely used for LA fermentation, resulting in increased production costs. Economic analysis of LA production showed that the cost 
of yeast extract contributed over $30 \%$ to the total production cost (Li at al., 2010). Therefore, alternatives to costly nutrient sources, based on agro-industry waste, have been studied intensively, e.g. corn steep liquor, spent yeast cells (Rivas et al., 2004), wheat gluten (Hetényi et al., 2010), and potato juice (Dishisha et al., 2013). Also, different strategies for supplementation of ingredients that efficiently support the growth of LAB have been evaluated, such as acid-based hydrolysis of fish wastes (Gao et al., 2006a), spent cells (Gao et al., 2006b) and rice bran (Gao et al., 2008), as well as enzymatic hydrolysis of whey proteins (Vasala et al., 2005), alfalfa green juice (Dietz et al., 2016) and cottonseed (Li et al., 2013) using commercially available proteases. However, data on utilization of proteolytic microbes as a simple and low-cost hydrolytic method are insufficiently presented in literature, although it could be an interesting alternative approach for economical LA production on complex waste substrates.

Industrial distillery stillage, wastewater from bioethanol production, is a cheap and abundant substrate that has been successfully used as alternative feedstock for LA and probiotic biomass production (Mladenović et al., 2016). Traditionally, the stillage was employed in animal nutrition after drying as dried distillers grains with solubles (DDGS) (Wood et al., 2014), but alternative possibilities such as production of biogas (Kaparaju et al., 2010), hydrogen (Luo et al., 2010) and edible fungal biomass (Pietrzak et al., 2016) were also proposed. The main objective of this study was to assess utilization of potato stillage in a two-stage fermentation process using Bacillus licheniformis TFUNS and Lactobacillus paracasei NRRL B-4564. In the first stage distillery stillage was pretreated with $B$. licheniformis which is an efficient producer of extracellular proteases, in order to increase free $\alpha$-amino nitrogen content in the waste substrate. In the subsequent stage, the LA fermentation with L. paracasei strain was performed. The results of the fermentation with proteolytically pretreated stillage (two-stage fermentation) were compared with untreated stillage (one-stage fermentation).

\section{MATERIALS AND METHODS}

\section{Microorganisms}

Bacillus licheniformis TFUNS, proteases producing strain, used in these experiments was originated from the collection of Department of Biotechnology and Pharmaceutical Engineering, Faculty of Technology (Novi Sad, Serbia) and Lactobacillus paracasei NRRL B-4564, a homofermentative L (+) lactic acid strain, was obtained from Northern Regional Research Laboratory (NRRL, Peoria, USA). B. licheniformis TFUNS was aerobically propagated with shaking (150 rpm, KS 4000i control, IKA $^{\circledR}$, Werke GmbH \& Co. KG, Staufen, Germany) at $37{ }^{\circ} \mathrm{C}$ for $18 \mathrm{~h}$ in nutrient broth before inoculation to fermentation medium. $L$. paracasei NRRL B-4564 was propagated under microaerophilic static conditions generated by Anaerocult ${ }^{\circledR} \mathrm{C}$ bags (Merck KGaA, Darmstadt, Germany) at 37 ${ }^{\circ} \mathrm{C}$ for $18 \mathrm{~h}$ in Man Rogosa Sharpe (MRS) broth. This prepared culture was used for initiation of LA fermentation.

\section{Substrate preparation}

The stillage remained after bioethanol production on wasted potato was obtained from Reahem ethanol plant (Reahem d.o.o., Srbobran, Serbia). After adjustment of the $\mathrm{pH}$ in the stillage to 7.0 with $30 \% \mathrm{NaOH}$ solution, it was sterilized at $121{ }^{\circ} \mathrm{C}$ for 15 minutes and used as a substrate.

\section{Fermentationof distillery stillage}

First stage of fermentation

In the first fermentation stage the proteolytic pretreatment of distillery stillage by $B$. licheniformis TFUNS was performed.
The fermentations were carried out as batch cultures, with shaking (150 rpm, KS 4000i control, IKA ${ }^{\circledR}$, Werke GmbH \& Co. KG, Staufen, Germany) in $500 \mathrm{~mL}$ flasks with $200 \mathrm{~mL}$ of the stillage. The fermentation was initiated by the addition of $2 \%$ $(\mathrm{v} / \mathrm{v})$ overnight seed culture and conducted at temperature of 37 ${ }^{\circ} \mathrm{C}$. The fermentation time was $120 \mathrm{~h}$. During the fermentation free $\alpha$-amino nitrogen concentration, reducing sugar concentration and number of viable cells were followed and approximately $2 \mathrm{~mL}$ of fermentation media was aseptically withdrawn for monitoring of important fermentation parameters.

\section{Second stage of fermentation}

After the pretreatment, solid part of the stillage with $B$. licheniformis biomass was removed by centrifugation (12000 $\mathrm{rpm}, 10 \mathrm{~min}$ ) and the liquid part was subsequently subjected to LA fermentation by $L$. paracasei NRRL B-4564. At the beginning of the LA fermentation, the sugar content of the stillage media was adjusted at approximately 25 g/L by addition of a concentrated glucose solution and the stillage was inoculated with $5 \%(\mathrm{v} / \mathrm{v})$ of the overnight culture of $L$. paracasei. LA fermentations were carried out as batch cultures with shaking (100 rpm) at temperature of $41{ }^{\circ} \mathrm{C}$, under microaerophilic conditions. During the fermentation samples were aseptically withdrawn and the substrate consumption, LA concentration and a number of living cells were further analyzed.

In parallel, LA fermentation of untreated liquid stillage was performed. The sugar concentration of untreated stillage media was also adjusted at approximately $25 \mathrm{~g} / \mathrm{L}$ by addition of a concentrated glucose solution and the stillage was inoculated with $5 \%(\mathrm{v} / \mathrm{v})$ of the overnight culture of L. paracasei.

Analytical methods

The free $\alpha$-amino nitrogen content in fermentation media was determined by ninhydrin method (Lie, 1973). The concentration of reducing sugars, calculated as glucose, was estimated by 3,5-dinitrosalicylic acid method (Miller, 1959). Calibration curve was set at $505 \mathrm{~nm}$ using standard glucose solutions. LA concentration was determined by enzymatic method (L-/ D-Lactic acid assay, Megazyme ${ }^{\circledR}$, Wicklow, Ireland) after deproteinization of the samples according to procedure prescribed in assay. Number of viable $L$. paracasei NRRL B-4564 and B. licheniformis TFUNS cells was estimated using pour plate technique on MRS and nutrient agar, respectively, after incubation for $48 \mathrm{~h}$ at $37^{\circ} \mathrm{C}$. All chemicals used in experiments were analytical grade.

\section{Statistical analysis}

The experiments were done in triplicates. All values are expressed as means \pm standard deviation. Mean values of treatments were compared by the analysis of variance. One-way ANOVA followed by Tukey's test was applied to evaluate the effect of investigated parameters. Differences were considered significant at $p<0.05$.

\section{RESULTS AN DISCUSSION}

\section{Fermentation of distillery stillage by $B$. licheniformis}

First stage of fermentation was performed using $B$. licheniformis in order to provide individual amino acids and small peptides, but also other growth promoting factors that could be beneficial for LAB. The changes in free $\alpha$-amino nitrogen concentration, sugar concentration and the kinetics of $B$. licheniformis TFUNS growth during fermentation of distillery stillage are presented in Fig. 1. 


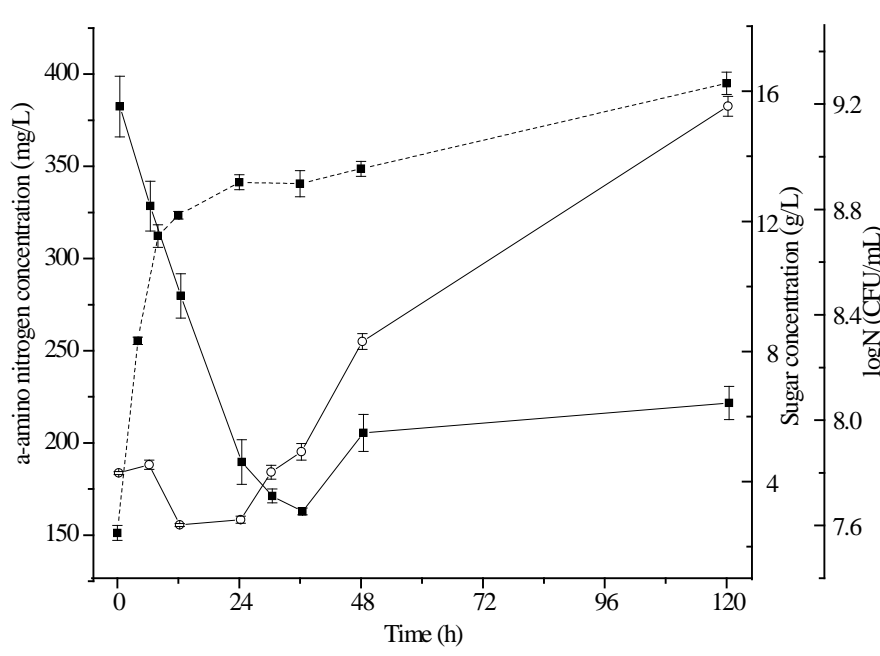

Fig. 1. Kinetic changes in free $\alpha$-amino nitrogen and reducing sugar concentration during fermentation of distillery stillage with B. licheniformis TFUNS. Symbols: solid symbols, solid line - sugar concentration, open symbols, solid line - free $\alpha$-amino nitrogen concentration, solid symbols, dashed line - the number of viable B. licheniformis TFUNS cells

As shown in Fig. 1, the concentration of free $\alpha$-amino nitrogen in the stillage has been significantly increased during fermentation by $B$. licheniformis. In general, the amount of assimilative nitrogen in media is a function of free $\alpha$-amino nitrogen levels (Appiah-Nkansah et al., 2018) and free $\alpha$-amino nitrogen content is mostly used for analysis of the degree of proteolysis (Djukić-Vuković et al., 2016). In present study, during the exponential and early stationary growth phase of $B$. licheniformis TFUNS, a decrease of free $\alpha$-amino nitrogen and reducing sugar concentration has been observed (Fig. 1). However, after $24 \mathrm{~h}$ a notable rise in the production of free $\alpha$ amino nitrogen was achieved. After $120 \mathrm{~h}$ of fermentation, free $\alpha$-nitrogen concentration in the stillage pretreated with $B$. licheniformis TFUNS was $107 \%$ higher $(382.60 \mathrm{mg} / \mathrm{L})$ compared to the initial value $(183.68 \mathrm{mg} / \mathrm{L})$. On the other hand, the concentration of sugars in the media was rapidly decreasing up to $24 \mathrm{~h}$ of fermentation in order to support fast biomass growth, after that a slight increase was detected towards the end of fermentation (Fig 1). The increase of free $\alpha$-nitrogen concentration during fermentation of the stillage by $B$. licheniformis TFUNS was a result of effective hydrolysis of the proteins present in the media by the activity of produced proteolytic enzymes. As many other members of the genus Bacillus, $B$. licheniformis is a highly efficient producer of the numerous extracellular hydrolytic enzymes and for decades, many $B$. licheniformis strains have been extensively used for fermentative production of enzymes, especially proteases and amylases (Voigt Birgit et al., 2014). In general, the production of extracellular proteases exhibits specific relationship with regard to the microbial growth phase, and it is a strain specific characteristic. Also, the synthesis of proteases in Bacillus species is inducible and dependent on the growth environment (Kumar and Hiroshi Takagi, 1999).

Usually, renewable and low-cost agro-industrial raw materials contain protein macromolecules which need to be further degraded into small peptide molecules and even amino acid before being utilized by LAB (Liu et al., 2017). Although, acid-based hydrolysis of different nitrogen sources has been frequently investigated in order to improve the utilization efficiency, data about application of proteolytic microbes for substrate treatment are still very limited. In a study of Vasala et al. (2006), Acinetobacter sp., Flavobacterium sp., Bacillus megaterium and Pseudomonas fluorescens were evaluated for their ability to improve the growth of LAB in cheese whey. $B$. megaterium pretreatment of whey-protein-containing media was suggested to be the best alternative to commercial protease treatment (Vasala et al., 2006). Based on the production kinetics of free $\alpha$-amino nitrogen during fermentation of potato stillage, it could be concluded that the stillage pretreatment with $B$. licheniformis is a simple method for enrichment of a complex waste substrate with easily assimilative nitrogen required for LA production.

Impact of the pretreatment of distillery stillage by proteolytic bacteria on lactic acid production by $L$. paracasei

In order to verify the effect of the stillage pretreatment on LA production, second stage fermentation was performed using proteolytically pretreated stillage as a substrate in LA fermentation by L. paracasei. The results of the fermentation of proteolytically pretreated stillage (two-stage fermentation) were compared with untreated stillage (one-stage fermentation). The time course of LA production and sugar consumption on the stillage pretreated by $B$. licheniformis TFUNS and untreated stillage is presented in Fig. 2. The main parameters of LA fermentation are presented in Table 1.

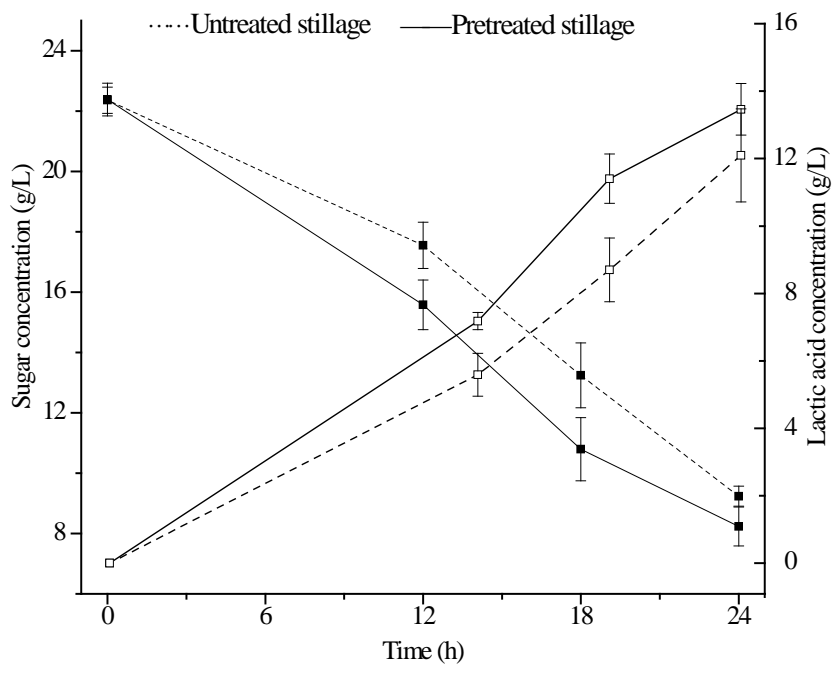

Fig. 2. Time course of LA production and sugar consumption in LA fermentation of proteolytically pretreated and untreated stillage by L. paracasei NRRL B-4564. Symbols: solid symbolssugar concentration, open symbols - lactic acid concentration

It can be noticed that the free $\alpha$-amino nitrogen content in the stillage significantly influenced fermentation kinetics. Faster sugar consumption and LA production in proteolytically pretreated media compared to untreated was observed at the beginning of LA fermentation. After $19 \mathrm{~h}$ of fermentation, LA concentration achieved in pretreated stillage was $48 \%$ higher than in untreated media. However, the maximal LA concentration obtained at the end of fermentation in the pretreated stillage was slightly higher $(13.46 \mathrm{~g} / \mathrm{L})$ than in untreated media $(12.09 \mathrm{~g} / \mathrm{L})$. Potato stillage has already been proven to be an efficient substrate for LA production and could be used as an adequate substitution for expensive commonly used nutrient sources in LA fermentation (Mladenović et al., 2016, Djukić-Vuković et al., 2016). Proteins in stillage originate from residual yeast biomass, but also from the substrate used for ethanol fermentation. In LA fermentation of potato stillage by $L$. 
rhamnosus ATCC 7469 maximal LA concentration of $46.21 \mathrm{~g} / \mathrm{L}$ with LA productivity of $1.28 \mathrm{~g} / \mathrm{L} \mathrm{h}$ was achieved (DjukićVuković et al., 2016). The importance of the free $\alpha$-amino nitrogen for the yeast fermentation has been well documented in literature and it is considered to be an important chemical parameter that significantly correlates to fermentation efficiently (Appiah-Nkansah et al., 2018). Beside for ethanol fermentation, the importance of free $\alpha$-amino nitrogen content for evaluation of wastes and renewable substrates for LA and biomass production has been also reported (DjukićVuković et al., 2016). In our present study, increase of the free $\alpha$-amino nitrogen in the media resulted in faster glucose uptake and LA production, and thus improved fermentation efficiency. Similar findings on improved ethanol production were also reported by AppiahNkansah et al., (2018). It was described earlier that proteolytic microbes could improve the amino acid composition of whey protein containing media and subsequently enhance the LA fermentation rate (Vasala et al., 2006). Almost equally efficient LA production as in our study was obtained by treating the medium with B. megaterium (Vasala et al., 2006).

The number of viable L. paracasei NRRL B-4564 cells in LA fermentation of pretreated and untreated stillage is presented in Fig. 3. Similarly to production of LA, the growth of $L$. paracasei in pretreated stillage was also better compared to that in untreated media, while the biomass of $L$. paracasei 10.0- $\begin{aligned} & \text { NRRL B-4564 obtained at the end of fermentation } \\ & \left(4.2 \times 10^{9} \mathrm{CFU} / \mathrm{mL}\right) \text { represents a highly valuable co- }\end{aligned}$

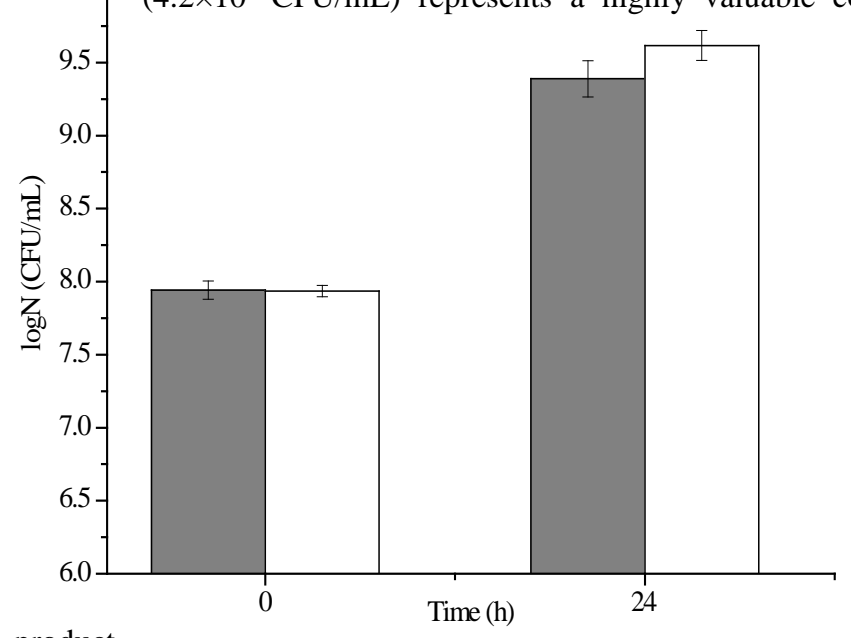

product.

Fig. 3. The number of viable L. paracasei NRRL B-4564 cells in LA fermentation of proteolytically pretreated and untreated stillage. Symbols: grey bars - untreated stillage, white bars pretreated stillage

The production of LAB biomass could be significant for several reasons. LAB have status of generally recognized as safe (GRAS) and many of LAB are constituents of gut microbiota in animals and humans (Gaggìa et al., 2010). As constituents of gut microbiota they are beneficial for general health mostly due to their probiotic activity. The probiotic characteristics of many $L$. paracasei strains have been extensively studied and well documented (Poddar et al., 2014). Due to the long history of safe use, L. paracasei has been granted Qualified Presumption of Safety (QPS) status which was introduced by the European Food Safety Authority (EFSA) for a premarket safety assessment of 4564. microorganisms used in food and feed production (EFSA, 2007). According to the Regulation on additives for use in animal nutrition (EC) $1831 / 2003$, L. paracasei is already classified to the category of technological additives and to the functional group of silage additives. L. paracasei NRRL B-4564 strain, used in present study, has also shown probiotic characteristics (our unpublished data), thus it could be considered that the probiotic biomass remained after LA fermentation on the potato stillage is suitable for application in animal nutrition.

Table 1. The values of significant parameters of LA fermentation of proteolytically pretreated and untreated stillage by L. paracasei NRRL B-

\begin{tabular}{||c|c|c|c|c|c||}
\hline \hline & $\begin{array}{c}\text { Fermentation } \\
\text { time (h) }\end{array}$ & $\begin{array}{c}\text { LA } \\
\text { concentration } \\
(\mathrm{g} / \mathrm{L})\end{array}$ & $\begin{array}{c}\text { LA yield } \\
(\mathrm{g} / \mathrm{g})\end{array}$ & $\begin{array}{c}\text { LA yield } \\
\text { coefficient } \\
(\mathrm{g} / \mathrm{g})\end{array}$ & $\begin{array}{c}\text { LA } \\
\text { productivity } \\
(\mathrm{g} / \mathrm{L} \mathrm{h})\end{array}$ \\
\hline \multirow{2}{*}{$\begin{array}{c}\text { Pretreated } \\
\text { stillage }\end{array}$} & 19 & $11.92 \pm 0.73$ & $0.51 \pm 0.06$ & & $0.60 \pm 0.02$ \\
\cline { 2 - 6 } & 24 & $13.46 \pm 0.76$ & $0.60 \pm 0.08$ & $0.95 \pm 0.06$ & $0.56 \pm 0.02$ \\
\hline $\begin{array}{c}\text { Untreated } \\
\text { stillage }\end{array}$ & 19 & $8.03 \pm 0.94$ & $0.40 \pm 0.09$ & & $0.46 \pm 0.03$ \\
\cline { 2 - 6 } & 24 & $12.09 \pm 1.37$ & $0.54 \pm 0.04$ & $0.93 \pm 0.08$ & $0.50 \pm 0.01$ \\
\hline
\end{tabular}

\section{CONCLUSIONS}

A strategy for valorization of complex waste substrate applying two-stage fermentation process for cost-effective production of LA and probiotic biomass was proposed. Pretreatment of distillery stillage by the proteolytically active $B$. licheniformis TFUNS strain could be effective alternative to provide easily assimilative nitrogen needed for $\mathrm{LAB}$, thus avoiding addition of costly sources commonly used for LA production. This presented type of fermentation process enables improved utilization of waste substrate for the production of high-value products.

ACKNOWLEDGMENTS: Research presented in this paper was funded by Ministry of Education, Science and Technological Development, Republic of Serbia, project number TR 31017 and Project \#I-1 of Scientific and Technological Collaboration of Republic of Serbia and PR China.

\section{REFERENCES}

Appiah-Nkansah, N.B., Zhang, K., Rooney, W., Wang, D. (2018). Ethanol production from mixtures of sweet sorghum juice and sorghum starch using very high gravity fermentation with urea supplementation. Industrial Crops and Products, 111, 247-253.

Barlow, S., Chesson, A., Collins, J.D., Dybing, E., Flynn, A., Fruijtier-Pölloth, C., Hardy, A., Knaap, A., Kuiper, H., Le Neindre, P., Schans, J. (2007). Introduction of a Qualified Presumption of Safety (QPS) approach for assessment of selected microorganisms referred to EFSA. Opinion of the Scientific Committee. EFSA Journal, 587, 1-16.

Dietz, D., Schneider, R., Papendiek, F., Venus, J. (2016). Leguminose green juice as an efficient nutrient for l (+)-lactic acid production. Journal of Biotechnology, 236, 26-34.

Dishisha, T., Ståhl, Å., Lundmark, S., Hatti-Kaul, R. (2013). An economical biorefinery process for propionic acid production from glycerol and potato juice using high cell density fermentation. Bioresource Technology, 135, 504-512.

Djukić-Vuković, Aleksandra, Mladenović, Dragana, Radosavljević, M., Kocić-Tanackov, Sunčica, Pejin, Jelena, Mojović, Ljiljana. (2016). Wastes from bioethanol and beer productions as substrates for $\mathrm{L}(+)$ lactic acid production-A comparative study. Waste Management, 48, 478-482. 
Gaggìa, Francesca, Mattarelli, Paola, Biavati, B. (2010). Probiotics and prebiotics in animal feeding for safe food production. International Journal of Food Microbiology, 141, S15-S28.

Gao, M.T., Hirata, M., Toorisaka, E., Hano, T. (2006a). Acidhydrolysis of fish wastes for lactic acid fermentation. Bioresource Technology, 97, 2414-2420.

Gao, M.T., Hirata, M., Toorisaka, E., Hano, T. (2006b). Study on acid-hydrolysis of spent cells for lactic acid fermentation. Biochemical Engineering Journal, 28, 87-91.

Gao, M.T., Kaneko, M., Hirata, M., Toorisaka, E., Hano, T. (2008). Utilization of rice bran as nutrient source for fermentative lactic acid production. Bioresource Technology, 99, 3659-3664.

Hetényi, K., Gál, K., Németh, Á., Sevella, B. (2010). Use of sweet sorghum juice for lactic acid fermentation: preliminary steps in a process optimization. Journal of Chemical Technology and Biotechnology, 85, 872-877.

Kaparaju, P., Serrano, M., Angelidaki, I. (2010). Optimization of biogas production from wheat straw stillage in UASB reactor. Applied Energy, 87, 3779-3783.

Kumar, C.G. and Takagi, H. (1999). Microbial alkaline proteases: from a bioindustrial viewpoint. Biotechnology Advances, 17, 561-594.

Li, Y., Wang, L., Ju, J., Yu, B., Ma, Y. (2013). Efficient production of polymer-grade D-lactate by Sporolactobacillus laevolacticus DSM442 with agricultural waste cottonseed as the sole nitrogen source. Bioresource Technology, 142, 186191.

Li, Z., Han, L., Ji, Y., Wang, X., Tan, T. (2010). Fermentative production of l-lactic acid from hydrolysate of wheat bran by Lactobacillus rhamnosus. Biochemical Engineering Journal, 49, 138-142.

Lie, S. (1973). The EBC-ninhydrin method for determination of free alpha amino nitrogen. Journal of the Institute of Brewing, 79, 37-41.

Liu, J., Zhou, J., Wang, L., Ma, Z., Zhao, G., Ge, Z., Zhu, H., Qiao, J. (2017). Improving nitrogen source utilization from defatted soybean meal for nisin production by enhancing proteolytic function of Lactococcus lactis F44. Scientific Reports, 7, 6189.
Miller, G.L. (1959). Use of dinitrosalicylic acid reagent for determination of reducing sugar. Analytical Chemistry, 31, 426-428.

Mladenović, Dragana, Pejin, Jelena, Kocić-Tanackov, Sunčica, Stefanović, Andrea, Đukić-Vuković, Aleksandra, Mojović, Ljiljana. (2016). Potato stillage and sugar beet molasses as a substrate for production of lactic acid and probiotic biomass. Journal on Processing and Energy in Agriculture, 20, 17-20.

Pietrzak, W., Kawa-Rygielska, J., Król, B., Lennartsson, P.R., Taherzadeh, M.J. (2016). Ethanol, feed components and fungal biomass production from field bean (Vicia faba var. equina) seeds in an integrated process. Bioresource Technology, 216, 69-76.

Poddar, D., Das, S., Jones, G., Palmer, J., Jameson, G.B., Haverkamp, R.G., Singh, H. (2014). Stability of probiotic Lactobacillus paracasei during storage as affected by the drying method. International Dairy Journal, 39, 1-7.

Rivas, B., Moldes, A.B., Dominguez, J.M., Parajó, J.C. (2004). Development of culture media containing spent yeast cells of Debaryomyces hansenii and corn steep liquor for lactic acid production with Lactobacillus rhamnosus. International Journal of Food Microbiology, 97, 93-98.

Thomsen, M.H., Guyot, J.P., Kiel, P. (2007). Batch fermentations on synthetic mixed sugar and starch medium with amylolytic lactic acid bacteria. Applied Microbiology and Biotechnology, 74, 540-546.

Vasala, A., Panula, J., Neubauer, P. (2005). Efficient lactic acid production from high salt containing dairy by-products by Lactobacillus salivarius ssp. salicinius with pre-treatment by proteolytic microorganisms. Journal of Biotechnology, 117, 421-431.

Voigt, B., Schroeter, R., Schweder, T., Jürgen, B., Albrecht, D., van Dijl, J.M., Maurer, K.H., Hecker, M. (2014). A proteomic view of cell physiology of the industrial workhorse Bacillus licheniformis. Journal of Biotechnology, 191, 139-149.

Wood, C., Rosentrater, K.A., Muthukumarappan, K. (2014). Techno-economic modeling of a corn based ethanol plant in 2011/2012. Industrial Crops and Products, 56, 145-155.

Received: 28. 02. 2018.

Accepted: 11. 08. 2018. 